\title{
Essential Matter
}

\section{THE BIBLE VOTE}

Religion and the New Right

By Peggy L. Shriver

National Council of Churches executive Peggy Shriver offers an insightful and objective analysis of the Moral Majority and similar groups.

"An invaluable tool for anyone concerned about the religious right."-Norman Lear $\$ 5.95$ paper

\section{THE OTHER SIDE OF THE COUCH}

What Psychotherapists Believe

Edited by Dr. E. Mark Stern

"Iwenty-four psychotherapists expound-briefly, simply, and in some cases quite compellingly-their personalprofessional credo." - Kirkus Reviews

"This will be of keen interest for everyone in or contemplating therapy."-Rollo May

"Destined to be a classic in our field." -John Warkentin, Ph.D., M.D.

$\$ 12.95$ cloth

\section{THE PERMANENT GOVERNMENT}

Who Really Runs New York?

By Jack Newfield and Paul Du Brul

Introduction by Ralph Nader

This extensively revised and updated guide to the channels of power in New York City government "could be the best piece of urban journalism since Lincoln Steffens."

-John Kenneth Galbraith,

$\$ 9.95$ paper

The New York Times Book Review

\section{LIVING BEYOND CRISIS}

Essays on Discovery and Being in the World Edited by Stephen C. Rowe

Essays by Adrienne Rich, Robert Jay Lifton, Hazel Henderson, Peter Marin, Rollo May, Hannah Arendt, Elisabeth Kübler-Ross, and eight other important social critics.

"A superb selection."

- Alan B. Anderson, Department of Religious Studies,

$\$ 8.95$ paper University of North Carolina at Greensboro

\section{NEW IMMIGRANTS}

Portraits in Passage

By Thomas Bentz

Preface by the Rev. Theodore M. Hesburgh

Thirteen immigrant families tell their stories - why they left their homelands and how they have adjusted to life in America.

"An eye-opening book."-Publishers Weekly

$\$ 7.95$ paper

\section{WITNESS TO THE HOLOCAUST}

Edited by Azriel Eisenberg

"Witness to the Holocaust brings us the words of thoselew and non-lew, Nazi and dissenter-who experienced firsthand the attempted annihilation of an entire people."

"A truly monumental piece of scholarship." -lewish Book News

$\$ 17.95$ cloth

\section{SHOPPING BAG LADIES}

Homeless Women Speak About Their Lives

By Ann Marie Rousseau

Preface by Alix Kates Shulman

"A fascinating view of women whose bodies and lives are as shapeless as the bags they carry."

- San Francisco Examiner-Chronicle

"This painful and eloquent book should open our eyes and hearts."

- The New York Times Book Review

109 B \& W photos, $\$ 16.95$ cloth

\section{THE BIG BUSINESS READER}

Essays on Corporate America

Edited by Mark Green and Robert Massie Jr.

Introduction by Ralph Nader

"This collection of 49 essays covers a wide swath of corporate abuse: air and water pollution, price-fixing, manufacture of hazardous products, and others.... consistently well reasoned."-ALA Booklist

"A mammoth compilation of strong, articulate articles." -West Coast Review of Books

\section{$\$ 4.95$ paper}

\section{SLOW COMING DARK}

Interviews on Death Row

By Doug Magee

"A strong statement of the inner feelings and attitudes of those who must try to live while waiting to die at the hands of the state."-Choice

"A fine and noble effort." - Village Voice

$\$ 10.95$ cloth

\section{IMAGES OF LABOR}

\section{A Bread and Roses Book}

Introduction by Irving Howe

Preface by Joan Mondale

Thirty-two artists portray the role of the worker in American society.

"Beautiful and inspiring.... Of special note is Irving Howe's excellent introduction on the historical and contemporary importance of the labor movement to workers' rights and the maintenance of a free society."-Library Journal

"A lovely and memorable book."-Minneapolis Tribune 32 full-color plates, $\$ 16.95$ paper, $\$ 29.95$ cloth

\section{THE JEWISH MYSTICAL TRADITION}

\section{By Ben Zion Bokser}

"The Jewish Mystical Tradition is an annotated anthology that allows us to understand sometimes obscure teachings while savoring the complexity of language, thought, and symbolism that make them so rich."

$$
\text { - Los Angeles Times Book Review }
$$

"Highly recommended."-Library Journal

$\$ 9.95$ paper, $\$ 14.95$ cloth

These important and distinguished books are available at your bookseller or directly from

\section{The Pilgrim Press}

132 West 31 Street, New York 10001 - Commonweal Free catalog on request 